Bangladesh Journal of Anatomy July 2012, Vol. 10 No. 2 pp 59-62

\title{
Photographic Estimation of Arch Height of Adult Bangladeshi Male
}

\author{
M. Tanveer Hossain Parash', Humaira Naushaba ${ }^{2}$, Md. Ashfaqur Rahman ${ }^{3}$, Sadia Choudhury Shimmi ${ }^{4}$
}

\begin{abstract}
Context: The height of the medial longitudinal arch of the foot is commonly thought to be a predisposing factor to injuries. High-arched runners exhibit more bony, ankle and lateral injuries but low-arched runners reveal a higher risk of soft tissue, knee and medial injuries. Moreover high-arched and low-arched people have greater rearfoot eversion excursions than those with normal arch structure. So, it is important to have relatively easy and reliable way to measure the height of foot arch. The most reliable and valid way of measuring the foot arch is by the arch height index measurement system (AHIMS). The AHIMS can be costly to buy or construct for a third world country like Bangladesh. An alternative idea developed recently involved the use of digital photography to assess the arch height.
\end{abstract}

Study design: Cross sectional, analytical type of study.

Place and period of the study: Department of Anatomy, Sir Salimullah Medical College, Dhaka from July 2010 to June 2011.

Materials and Method: A total number of 110 medical students of $3^{\text {rd }}$ and $4^{\text {th }}$ year were chosen by purposive sampling.

Results: The values of arch height were $6.04 \mathrm{~cm}$ to $8.78 \mathrm{~cm}$ in sitting position and $4.83 \mathrm{~cm}$ to $7.03 \mathrm{~cm}$ in standing position respectively.

Key words: Foot arch, Arch Height, Digital photography.

Introduction:

The body weight is transmitted to the ground through the foot. The small size of it in relation to the rest of the body places an enormous burden upon it ${ }^{1}$. There are some combination of abnormal structure and mechanics in the foot that may put an individual at an increased risk for injury. The height of the medial longitudinal arch of the foot is commonly thought to be a predisposing factor to injuries. Medial longitudinal arch is the most important arch of the foot from a clinical point of view. The bony shape, the ligaments of the foot, and the muscular tones all play an important role in supporting the $\mathrm{arch}^{2}$.

1. Assistant Professor, Department of Anatomy, Monno Medical College, Gilondo, Manikgonj.

2. Professor and Head, Department of Anatomy, Sir Salimullah Medical College, Dhaka

3. Associate Professor, Department of Anatomy, Monno Medical College, Gilondo, Manikgonj.

4. Assistant Professor, Department of Physiology, Delta Medical College, Dhaka

Correspondence: Dr. M. Tanveer Hossain Parash
Williams et al. reported that high-arched runners exhibited more bony, ankle and lateral injuries but low-arched runners revealed a higher risk of soft tissue, knee and medial injuries ${ }^{3}$. Kernozek and Ricard (1990) found that both high-arched and lowarched people had greater rearfoot eversion excursions than those with normal arch structure ${ }^{4}$.

Several methods have been used to measure the arch height. Williams and McClay indicated that most reliable and valid way to measure the arch height is arch height index measurement system $(\text { AHIMS })^{5}$. The AHIMS can be costly to buy or construct for a third world country like Bangladesh. Digital photographic techniques potentially offer a highly practical, convenient and cost effective method of assessing arch structure within a clinical or laboratory setting ${ }^{4}$.

\section{Materials:}

The study was cross sectional, and analytical in nature. The study was carried out from July 2010 to 
June 2011 in the Department of Anatomy, Sir Salimullah Medical College, Dhaka. A total number of 110 medical students of $3^{\text {rd }}$ and $4^{\text {th }}$ year were chosen by purposive sampling.

\section{Methods:}

The foot length was measured when the subject was sitting in a relaxed position putting same weight on the both foot after taking off the shoes and the stockings. The ankle was perpendicular to the foot. The fixed jaw of the caliper was placed on pternion (most backward and prominent posterior point of the heel) and the sliding jaw was fixed on acropodion (most distal tip of the medial maleolus). The caliper was kept parallel to the long axis of the foot. Two $4.5 \mathrm{~cm}$ thick wooden blocks (A) were taken. One of them was placed under the heel (in front of the red dotted line) and the other one was placed under the metatarsal heads of right foot leaving the arch unsupported. The left foot was placed $15 \mathrm{~cm}$ left to the right foot on a $4.5 \mathrm{~cm}$ high weight machine (B) so that the distal end of the hallux of the left foot was positioned $5 \mathrm{~cm}$ behind the heel (red dotted line on $A$ ) of the right foot. This ensured clear view of the medial aspect of the right foot. A digital camera (C) was positioned on a $4 \mathrm{~cm}$ thick wooden block at a fixed distance of $55 \mathrm{~cm}$ from the medial border of the right foot and $10 \mathrm{~cm}$ forward to the back of the heel. Then the photographs were taken with fixed light and fixed focus on the foot with a fixed zoom ${ }^{3}$.

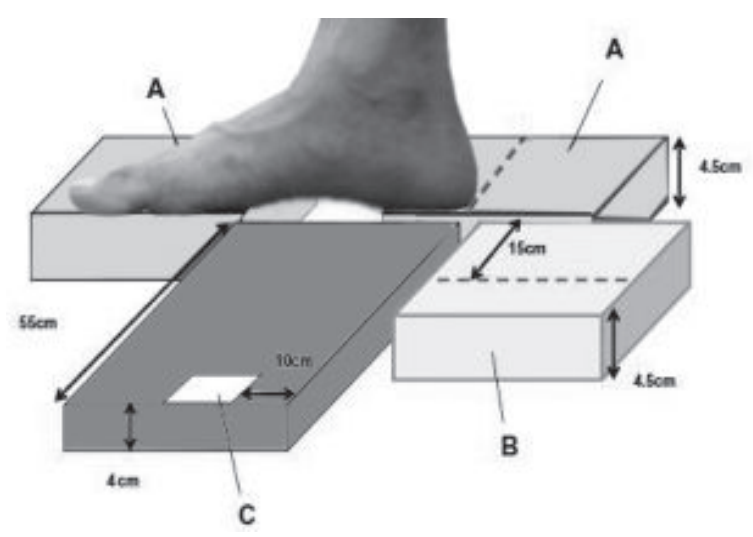

Fig.-1: Diagrammatic representation of set up for photographic measurement; Here A: wooden block for keeping the right foot, B: wooden block for keeping the left foot and $\mathbf{C}$ : place for keeping camera for taking photograph ${ }^{3}$.
All photographs were then transferred to the computer. No enhancements or modifications were made to any of the digital images. The measurements of arch height were taken using the program Adobe Photoshop 7.0. The foot length was measured by digitizing points at the pternion and the acropodion. The total foot length was then halved to determine $50 \%$ of the total length. A vertical line was then drawn at the half of the foot perpendicular from the supporting surface to the dorsum of the foot. The arch height is determined by digitizing coordinates at the top and bottom of this line. The measured photographic values were multiplied by the corresponding conversion factor to estimate the actual value. Conversion factor for foot length was calculated by dividing the foot length measured by foot caliper with the photographic foot length ${ }^{6}$.

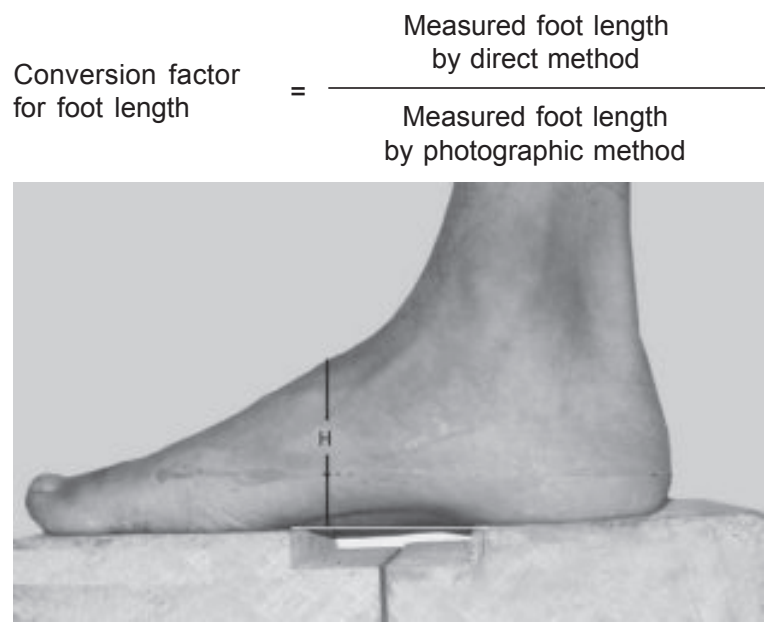

Fig.-2: Photographic measurement of the arch height $(H)$.

\section{Data analysis:}

The data were analyzed with the help of SPSS version 16.0 program keeping in view the objective of the study.

\section{Results:}

Table-l shows the mean ( \pm SD) of arch height of the right foot of 110 males of 20-25 years in sitting and standing positions with difference and level of significance. The values of arch height were 6.04 $\mathrm{cm}$ to $8.78 \mathrm{~cm}$ in sitting position and $4.83 \mathrm{~cm}$ to 7.03 $\mathrm{cm}$ in standing position respectively (Fig.3). The arch height decreased significantly $(0.80, p=0.000)$ with the variation of weight bearing condition. 
Bangladesh J. Anat. 2012; 10(2) : 59-62

Table-I

Arch height of right foot in sitting and standing position with difference and level of significance $(n=100)$ :

\begin{tabular}{lcccc}
\hline & \multicolumn{2}{c}{ Arch height } & \multicolumn{2}{c}{ Difference in sitting and } \\
& Mean & \pm SD & Pronding position \\
& Propon & $p$ \\
\hline Sitting position $(10 \% \mathrm{WB})$ & $7.00 \mathrm{~cm}$ & $0.55 \mathrm{~cm}$ & 0.80 & $0.000^{* *}$ \\
Standing position $(50 \% \mathrm{WB})$ & $5.60 \mathrm{~cm}$ & $0.44 \mathrm{~cm}$ & & \\
\hline
\end{tabular}

** $=$ significant at $5 \%$ level of significance

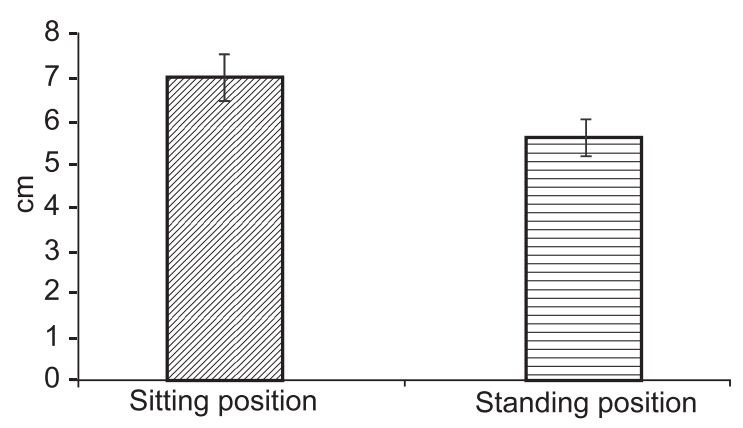

Fig.3 Arch height of adult Bangladeshi male in sitting and standing position $(n=110)$

\section{Discussion:}

The mean arch height of right foot of the subject in the present study was lower than that of the American $^{1,3,4}$ Hong Kong Chinese ${ }^{7}$ and Iranian ${ }^{8}$ adult male.

There was no available study on these variables of population having similar nutritional status as the present study. Along with this racial and genetic variation may play an important role compounding to the dissimilarity.

\section{Conclusion:}

The photographic method of measuring the arch height can be used in every age group, sex and ethnicity to develop a baseline data. This cost effective, easy method would help the clinicians in diagnosis and management accordingly.

\section{References:}

1. Pohl MB, Farr L. A composition of foot arch measurement reliability using both digital photography and caliper method. J FootAnkle Res [serial online] 2010 Jul 14; [6 screens]. Available from: URL: http:// www.ncbi.
nlm.nih.gov/pmc/articles/PMC2914096/ [accessed on 12.10.2010]

2. Chang YW, Hung W, Wu HW, Chiu YC, Hsu $\mathrm{HC}$. Measurements of Foot Arch in Standing, Level Walking, Vertical Jump and Sprint Start. International Journal of Sport and Exercise Science [serial online] 2010 Jun 28 [cited 2012 Feb17];2(2):31-8. Available from: URL: http:// web.nchu.edu.tw/ biosimulation/journal/pdf/ vol-2-no02/vol-2-no.2-b-0002.pdf [accessed on 05.11.2010]

3. Richards CJ, Card K, Song J, Hilstrom H. A novel arch height index assessment: intra-rater reliability. [online] 2003; [2 srceens]. Available from: URL: http://www.staffs.ac.uk/isb-fw/ Abstracts/ RICHARDS_A_NOVEL.pdf [accessed on 02.11.2010]

4. McPoil GT, Vicenzio B, Cornwall MW, Collins N. Can foot anthropometric measurements predict dynamic plantar surface contact area? J Foot Ankle Res [serial online] 2009 Oct; 2:28. Available from: URL: http:// www.jfootankleres.com/content/2/ 1/28 [accessed on 25.12.2012]

5. WIliams DS, McClay IS, Hamill J, Buchanan TS. Lower extremity kinematic and kinetic differences in runners with high and low arches. Journal Of Applied Biomechanics[serial online] 2001;17: 153-163 Available from: URL: http://www.udel.edu/PT/ davis/Williams_2001.pdf [accessed on 25.10.2012]

6. Akhter P. An anthropometric study of lower limb segment lengths measure-ments and their relationship with the stature and 
measurements of ultrasonographic fetal variables and their relationship with the maternal stature and determination of somatotype, footshape of Bangladeshi adult Muslim females [thesis]. Bangabandhu Sheikh Mujib Medical University; Dhaka: 2006.

7. Goonetileke RS, Ho ECF, So RHY. Foot anthropometry in Hong Kong. 1997. In: Proceedings of the ASEAN 97 Conference (pp. 81-88). Kuala Lumpur, Malaysia. Available from: URL: http:// ihome.ust.hk/ imhcf/ papers/aseanfoo.pdf [accessed on 25.10.2010]

8. Kanaani JM, Mortazavi SB, Khavanin A, Mirzai R, Rasulzadeh Y, Mansurizadeh M. Foot anthropometry of $18-25$ years old Iranian male students. Asian Journal of Scientific Research [serial online] 2010;3(1):62-9. Available from: URL: http://docsdrive.com/pdfs/ansinet/ ajsr/ 2010/62-69.pdf [accessed on 28.10.2010]. 